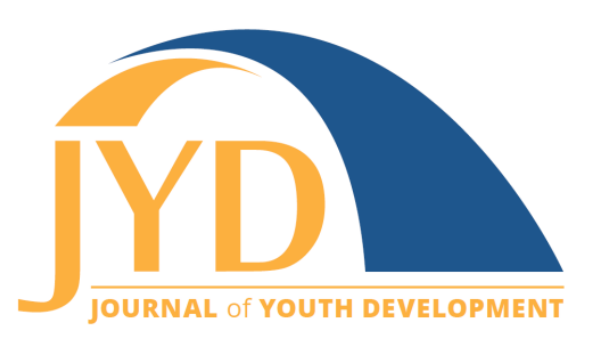

http://jyd.pitt.edu/ | Vol. 15 Issue 6 DOI 10.5195/jyd.2020.964 | ISSN 2325-4017 (online)

\title{
Kids Growing With Grains: Connecting Agriculture, Nutrition, and Environmental Literacy
}

\author{
Rachel Bayer \\ University of Maryland Extension \\ rachel.bayer@usda.gov \\ Ashley Travis \\ University of Maryland Extension \\ ashley90@umd.edu \\ Chenzi Wang \\ University of Maryland Extension \\ czw0017@umd.edu
}

\begin{abstract}
Kids Growing with Grains is a school-based agricultural education program that improves youths' conceptual understanding of how agriculture is linked to nutrition, the environment, and human health. University of Maryland Extension Educators developed the program's hands-on activities, which focus on grain science, grains and the environment, grains and animals, and grain nutrition. The program is traditionally implemented through a station-based field trip experience lasting 4 hours in length. The program has been evaluated using a mixed-methods approach that includes qualitative and quantitative data collected from both teachers and students. Evaluation results from the past 2 years indicate the program is achieving its learning objectives. The program is designed to be easily replicated by other Extension programs throughout the country in a variety of formal or non-formal settings.
\end{abstract}

Key words: agricultural literacy, nutrition literacy, environmental literacy, field trips

\section{Introduction}

Agriculture, the environment, and nutrition are inextricably linked, with each component impacting and relying on the other. However, in our rapidly urbanizing society the majority of people are removed from agriculture, making its importance in our daily lives-particularly

(cc) EY New articles in this journal are licensed under a Creative Commons Attribution 4.0 License. This journal is published by the University Library System, University of Pittsburgh and is cosponsored by the University of Pittsburgh Press. The Journal of Youth Development is the official peer-reviewed publication of the National Association of Extension 4-H Youth Development Professionals and the National AfterSchool Association. 


\section{Kids Growing With Grains}

regarding where and how food is produced and the connection between agriculture and the environment-less apparent to most individuals (Balschweid et al., 1998).

This is the case in Maryland, where agriculture is the state's largest commercial industry and single largest land use, but only employs $5.8 \%$ of the state's six million people (Maryland State Archives, 2019). The remaining population is several generations removed from the agricultural industry. The increasing disconnect between agricultural consumers and producers poses a challenge for a strong and sustainable agricultural industry in Maryland (Barczewski et al., 2016).

At the same time that agricultural literacy is declining, obesity is increasing. Childhood obesity rates have doubled in the United States over the last 30 years (Vierregger et al., 2015). As of 2018 in Maryland, $14.5 \%$ of 10 - to 17 -year-olds and $30.9 \%$ of adults were obese (State of Childhood Obesity, n.d.).

Likewise, McBeth and Volk (2010) found that while middle school students have moderate to high levels of environmental understanding, they (in a pattern echoing that of adults) lack the critical thinking and decision-making skills needed to resolve environmental issues for long-term sustainability and human health.

Hands-on, experiential lessons can address some of these issues. Well-designed and implemented programs (particularly in school environments) can promote healthy eating (Vierregger et al., 2015). Likewise, hands-on experiences with agriculture have been shown to significantly increase youth knowledge (Platt et al., 2008). Interactive activities enable youth to relate to agriculture, thereby heightening their interest in agriculture (Luckey et al., 2013). Additionally, by improving science and agricultural literacy, along with developing connections to nature and critical thinking skills, youth development professionals can help facilitate the development of environmentally responsible behaviors required for a sustainable future (Pennisi \& Lackey, 2018).

In light of these findings, two counties in Maryland implemented Kids Growing with Grains, a comprehensive program used to improve third and fourth graders' agricultural, environmental, and nutrition literacy. The program targets the themes of grain science, grain nutrition, grains and animals, and grains and the environment. The program's flexibility allows it to be implemented as an in-school field trip or utilized during out-of-school-time settings. The program's lessons can be taught individually or combined to provide stations for youth to rotate 


\section{Kids Growing With Grains}

through. Both facilitation methods provide hands-on learning so youth can better understand the connections between agriculture, the environment, and human health.

\section{Methods}

\section{Program Design}

The Kids Growing with Grains program historically provided agricultural-based field trips to fourth-grade students in Maryland's western counties. Students traveled to the Western Maryland Research and Education Center (WMREC), one of the University of Maryland's College of Agriculture and Natural Resources Agricultural Experiment Stations, for these field trips. The field trips consisted of having youth rotate in groups through four or five stations (depending on available time) focused on the types of grains, how they are grown, what they are used for, and how they are consumed. From 2012 to 2016 the program reached 3,633 individuals (2,100 in Frederick County and 1,533 in Washington County).

Following staffing changes in 2017, the program was redesigned to further meet audience needs and focus on improving the agricultural, environmental, and nutritional literacy of Maryland's youth. The program now focuses on developing students' conceptual understanding of how agriculture is linked to nutrition, the environment, and human health, through experiential learning. Developing this conceptual understanding enables youth to apply their learning in new situations and learning environments in order to grow their knowledge. In addition, because the program utilizes the experiential learning model, youth are better able to connect and apply what they are learning to their daily lives.

The updated program was designed with three main concepts in mind: (a) a new curriculum designed to engage students in exploring the intersection of agriculture, nutrition, and the environment; (b) a feeder pattern that ties this curriculum across grade levels and integrates holistically into in-school or out-of-school time programming; and (c) a delivery designed to meet the needs of underserved audiences. The program currently provides in-school field trips in the spring for third graders (due to school field trip and funding limitations) and an updated version of the WMREC field trips in the fall for fourth graders.

The program emphasizes reaching Title I schools, which are schools with large concentrations of low-income students that meet federal requirements to receive additional funds to assist in meeting student's educational goals. The program targets Title I schools as these at-risk youth might not otherwise receive an engaging, hands-on, agricultural education experience. Schools 
participating in both the third-grade in-school field trips in the spring and the fourth-grade WMREC field trips in the fall are Title I schools. Many of these schools also have a high percentage of Hispanic students.

\section{Kids Growing With Grains Lessons}

The field trips followed a station-based approach, with all students completing four stations focused on the topics of grain science, grain nutrition, grains and the environment, and grains and animals. Some students also completed an additional fifth station focused on grain nutrition, depending upon the time available. Each station lasted 30 to 45 minutes and provided an experiential learning opportunity on a given topic. Experiential learning is a key component of the program's curriculum. Utilizing the experiential learning model results in a deeper understanding of the subject matter and helps develop critical thinking skills. The appendix provides an overview of the Kids Growing with Grain learning station objectives and the experiential learning opportunities for the third-grade, in-school field trip and fourth-grade field trip to WMREC.

The students received workbooks to complete during the field trips that connected the lessons to their classroom instruction. These workbooks also contained family engagement pages and recipes (both with Spanish translations) to extend the learning into the home environment.

In addition, some students in Frederick County may have completed pre- and post-field trip activities with their teachers that connected field trip activities with math and literacy standards. The pre-field trip activity book included agriculture-focused math activities tied to the Common Core Standards for math. After each field trip, classrooms in Frederick County received a book and lesson plan to serve as a post-field trip activity. Third-grade classrooms received "Dirt: The Scoop on Soil" and fourth-grade classrooms received "How Did That Get in My Lunch Box? The Story of Food." Whether or not students completed the pre- and post-field trip activities was determined by their teachers, largely based on time constraints.

While the Kids Growing with Grains program has been implemented mainly as a school field trip, the stations have also been implemented as stand-alone lessons in out-of-school time settings, such as summer camps and during after-school programs. 


\section{Participants}

From 2017 through 2019, the program reached 3,076 participants (1,957 in Frederick County and 1,119 in Washington County) from 14 schools (five in Frederick County, nine in Washington County), providing over 21,504 contact hours of positive youth development and experiential agricultural education. Slightly over half (57\%) of program participants were from Title I schools.

\section{Evaluation Design}

A mixed-methods design was used to evaluate the program, drawing information from teacher and student survey responses, as well as from student-written thank-you notes. The details of each are below.

- Student and teacher surveys: After participating in the field trip, students individually completed a quantitative survey with four or five questions (yes or no responses). Teachers also completed an eight-question survey containing both qualitative and quantitative questions (yes/no and a 5-point Likert scale) as well as demographic questions for their students.

- Student-written thank-you notes: Within one week of participating in the program, teachers had students write thank you notes. Teachers were instructed to use the provided script (which was approved by the University of Maryland's Institutional Review Board) and not prompt students on what to write and/or draw. This was done to provide an accurate evaluation of what concepts students remembered on their own without prompting.

\section{Analysis Method}

For the student surveys, the percentage of students responding yes or no to each question was calculated. Student thank-you notes were coded according to which station(s) the youth mentioned either in writing, via drawing, or both. The number of stations mentioned in the thank-you notes was recorded and the percentage of students writing and/or drawing about one, two, three, or four stations was calculated.

For the teacher surveys, the mean was calculated for the Likert-based responses. In addition, a Kruskal-Wallis test was conducted to assess the differences in teacher evaluation of the students' overall experience at the learning stations. SPSS version 25 for Windows was used to 
analyze data. The open-ended survey questions on the teacher evaluation were also coded and analyzed for recurring themes.

\section{Ethics}

The Institutional Review Board for the University of Maryland approved the teacher and student surveys, as well as thank-you notes that assess program impact. Each parent received a letter notifying them of the research study and giving them the opportunity to opt their child out of the study. Assent information was read to the youth by the educator before taking the survey. All children were able to fully participate in the Kids Growing with Grains program even if they were not part of the study. To maintain anonymity, students were asked to not write their names on their surveys or thank-you notes.

\section{Results}

Cumulative evaluations from both grade levels for the student post surveys indicated that over $93.5 \%$ of students understood four of the concepts that were presented, $86.8 \%$ or more understood the remaining two concepts, and $72 \%$ intend to take action. Figure 1 summarizes the student survey results.

\section{Figure 1. Student Survey Results}

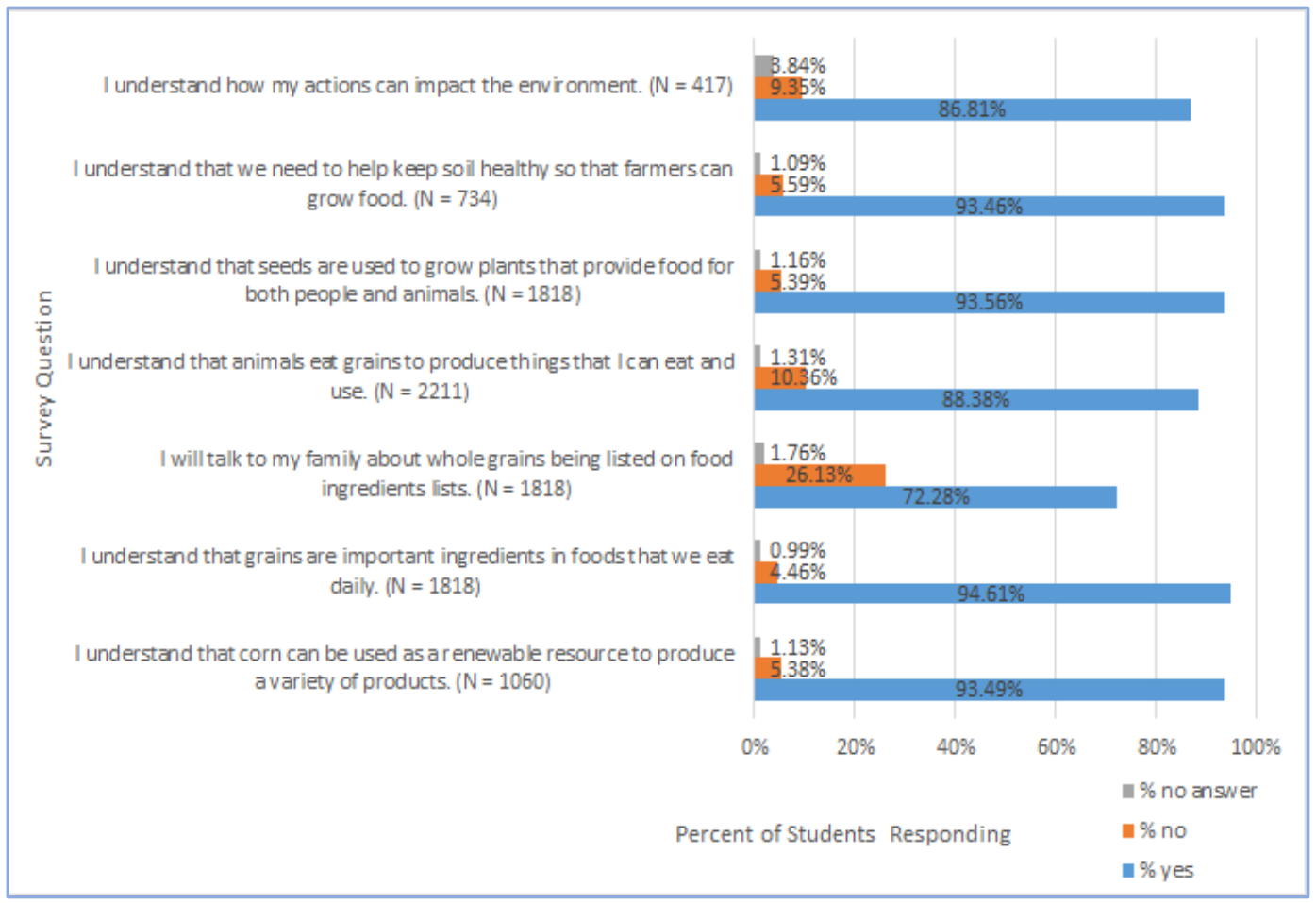


Analysis of student thank-you notes $(N=910)$ from both grade levels showed that $53.7 \%$ recalled and mentioned grain nutrition, 50.3\% recalled and mentioned grains and animals, and $50.6 \%$ recalled and mentioned grains and environment, and 39.3\% recalled and mentioned corn science. Figure 2 combines third- and fourth-grade results to show the percentage of students that mentioned each station (via writing, drawing, or both) in their thank-you note while Figure 3 shows the percentage of students mentioning each station by grade level.

Figure 2. Percentage of Student Thank You Note Responses Mentioning Each Station $(\mathrm{N}=910)$

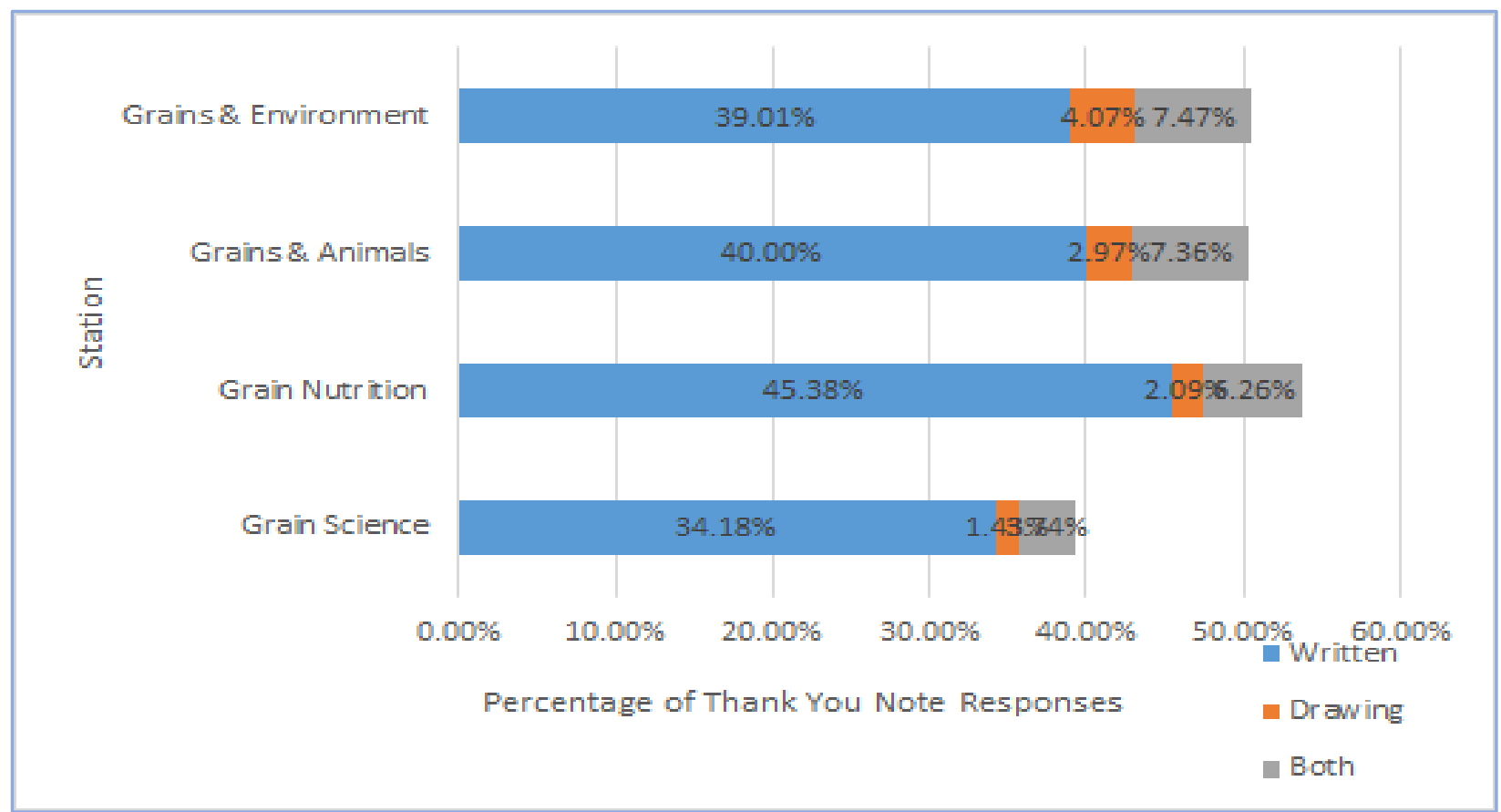


Figure 3. Percentage of Student Thank-You Note Responses Mentioning Each Station (via Drawing and/or Writing) By Grade Level

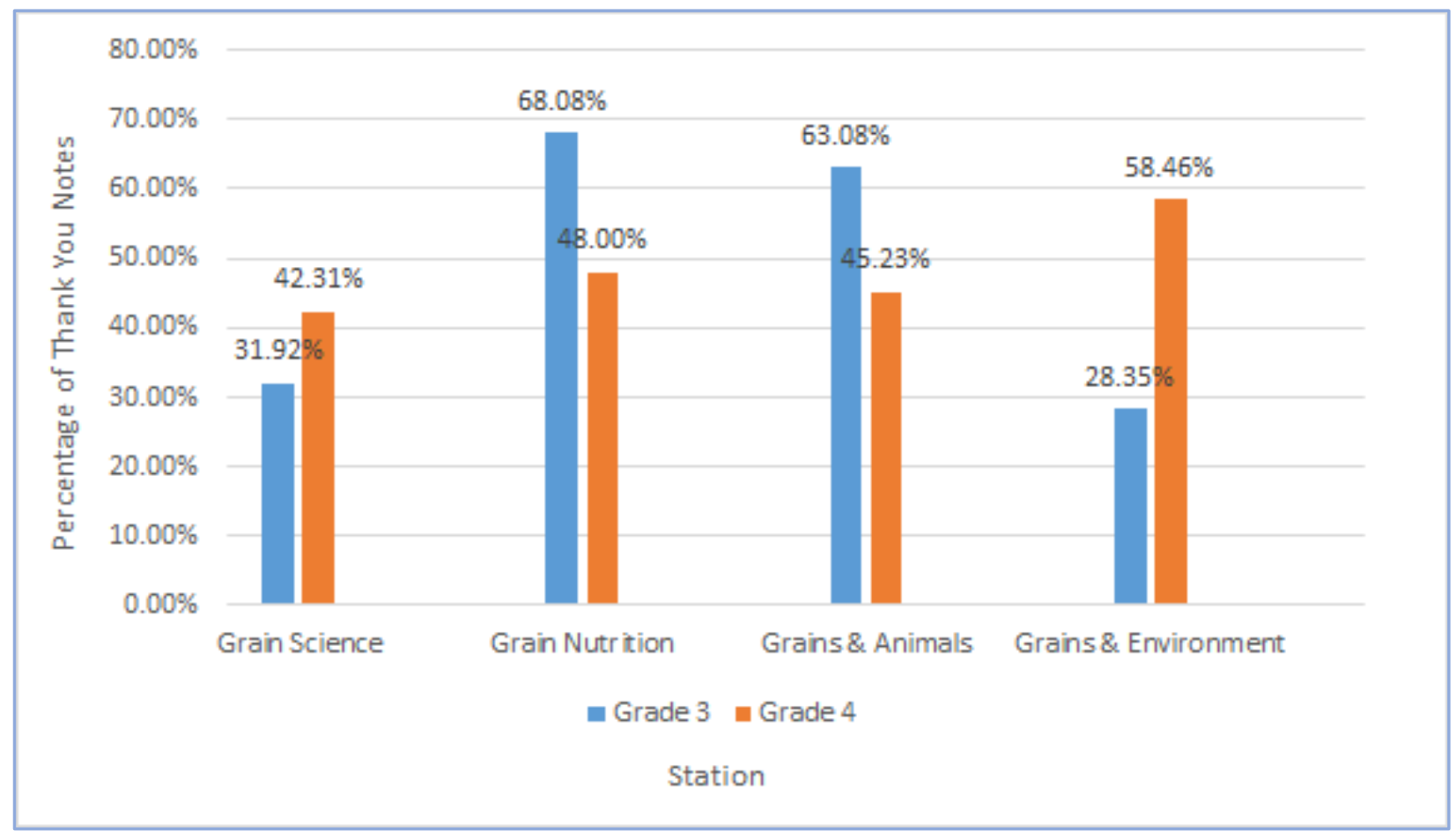

Note. $N_{\text {Grade } 3}=260, N_{\text {Grade } 4}=650$

In particular, written responses showed how learning objectives were met across grade level and the depth to which many students understood the concepts discussed during each station. Table 1 provides details regarding the station learning objectives and student quotes that support the learning of that objective. 
Table 1. Station Learning Objectives by Grade with Supporting Student Thank You Note Quotes

\section{Learning objectives}

Grade 3

Grade 4

\section{Grain science station}

Students describe the different parts of grain, using corn kernels as an example. Students explore how plants grow and the role of seeds in the plant life cycle. Students identify various uses of corn.

\section{Student Quotes}

- I also liked the corn and edamame bean station where we got to eat the corn and dissect it [cut it in half].

- It was fun to cut and see what it looked in the middle of the seeds.

- We played a game, we figured out what is made of corn and we touch corn that we eat and the cows eat.

- I learned a lot, like that corn was a grain, I didn't know that before.

- One thing I learned is that the tip cap is the attachment point of the kernel to the cob.
Students identify food products containing corn, the various uses of corn, and the role of corn in renewable resources, biodegradable products, and biofuels.

\section{Student Quotes}

- Also I enjoyed corn science. This was fun because we did an experiment where we put two different kinds of peanuts in water to see what was better for the environment.

- My favorite part was when we made the putty and I made some more at home and it feels so good and I made all of them for my family.

- I learned that corn is not just to eat, it is used in many other uses. 
Kids Growing With Grains

Table 1. (continued)

\section{Learning objectives}

Grade 3

\section{Grain nutrition station}

Students explore what makes a whole grain and the health benefits of eating whole grains. Students evaluate food labels to assess the nutritional content of their food.

\section{Student Quotes}

- I learned that the germ is the only living part of the corn kernel.

- I learned that there's something called the germ, but it's short for germinate.

- I learned that whole grains have all three parts because it fills your stomach.

- I learned that whole grain products have the bran, endosperm, and germ.

- I loved your pizza recipe. It is great I made it for my family. They said it was good.
Students compare and contrast different types of whole grain products, as well as the differences between whole and refined grains. Students understand how grains fit into the MyPlate dietary recommendation guidelines. Students explore the process of making whole grain products.

\section{Student Quotes}

- I learned that grains are healthy and we should eat some things that have grains. Also that we should look at nutrition facts to make sure you're eating healthy.

- My favorite station was the one where we made bread because I went home and baked it and it was so good that I had to share it with my family.

- I didn't know grains had different parts of the seed to make us healthy!

- I learned about whole wheat and how they grind down wheat.

- I went home and I looked for the yellow sticker [whole grains] and I found it and showed it to my mom. 
Table 1. (continued)

\begin{tabular}{|c|c|}
\hline \multicolumn{2}{|c|}{ Learning objectives } \\
\hline Grade 3 & Grade 4 \\
\hline \multicolumn{2}{|c|}{ Grains and animals station } \\
\hline $\begin{array}{l}\text { Students identify the variety of products and uses } \\
\text { people have for chickens and their eggs. Students } \\
\text { explore the parts of an egg. Students discuss animal } \\
\text { food, nutrition, and proper caretaking. } \\
\text { Student Quotes } \\
\text { - I learned that we can tell what color egg the hen is } \\
\text { going to have by the color of the hens ear. } \\
\text { - I learned that there are different parts to an egg. }\end{array}$ & $\begin{array}{l}\text { Students observe farm animals (livestock) and describe } \\
\text { their connection to agriculture and people. Students } \\
\text { discuss proper feeding and nutrition for these animals. } \\
\text { Student Quotes } \\
\text { - I learned that cow's have pretty big tongues, if they } \\
\text { don't want something they use their tongues to get } \\
\text { the stuff they like. But actually farmers grind up } \\
\text { their food so the cow's have to eat all of it. } \\
\text { - I liked petting the cow because I've never seen one } \\
\text { before in my whole entire life. } \\
\text { We learned so much about Agriculture and how the } \\
\text { cow, chickens, and goats digestive systems are } \\
\text { similar and different. Like how the cow has } 1 \\
\text { stomach and } 4 \text { compartments inside of it (The } \\
\text { stomach). }\end{array}$ \\
\hline \multicolumn{2}{|c|}{ Grains and environment station } \\
\hline $\begin{array}{l}\text { Students explain the composition of soil. Students } \\
\text { explore how water quality is impacted by different } \\
\text { types of ground surface coverings. } \\
\text { Student Quotes } \\
\text { - My favorite thing was plants because we got to feel } \\
\text { sand, clay, and silt. } \\
\text { - I learned that if we're littering, which means } \\
\text { pollution, its bad for the environment. } \\
\text { - The experiment with dirt was very cool. } \\
\text { - I liked the station when we learned about soil, and } \\
\text { about pollution and how it's bad for the } \\
\text { environment. } \\
\text { - I never knew dirt was a science word. I never } \\
\text { thought soil is made of so many things. }\end{array}$ & $\begin{array}{l}\text { Students analyze how grains are planted, grown, and } \\
\text { harvested. Students identify various types of grains } \\
\text { including corn, wheat, soybeans, oats, and barley. } \\
\qquad \text { Student Quotes } \\
\text { - I loved the decoration that we made with oats, } \\
\text { soybeans, corn, wheat, and barley. . . . I have also } \\
\text { been reminding my parents to drink and eat healthy. } \\
\text { - When we made those seed container I realize that } \\
\text { those seeds were seed that come from a plant. } \\
\text { - I learned that there are } 5 \text { types of grains: wheat, } \\
\text { soybeans, corn, oats, and barley. }\end{array}$ \\
\hline
\end{tabular}


In addition, 32\% of the students remembered three to four stations within 1 week of the field trip, and 30\% remembered two stations. Figure 4 summarizes the number of stations remembered by students (as expressed in their thank-you notes) across both grade levels.

Figure 4. Percentage of Students Remembering Zero to Four Stations by Grade Level

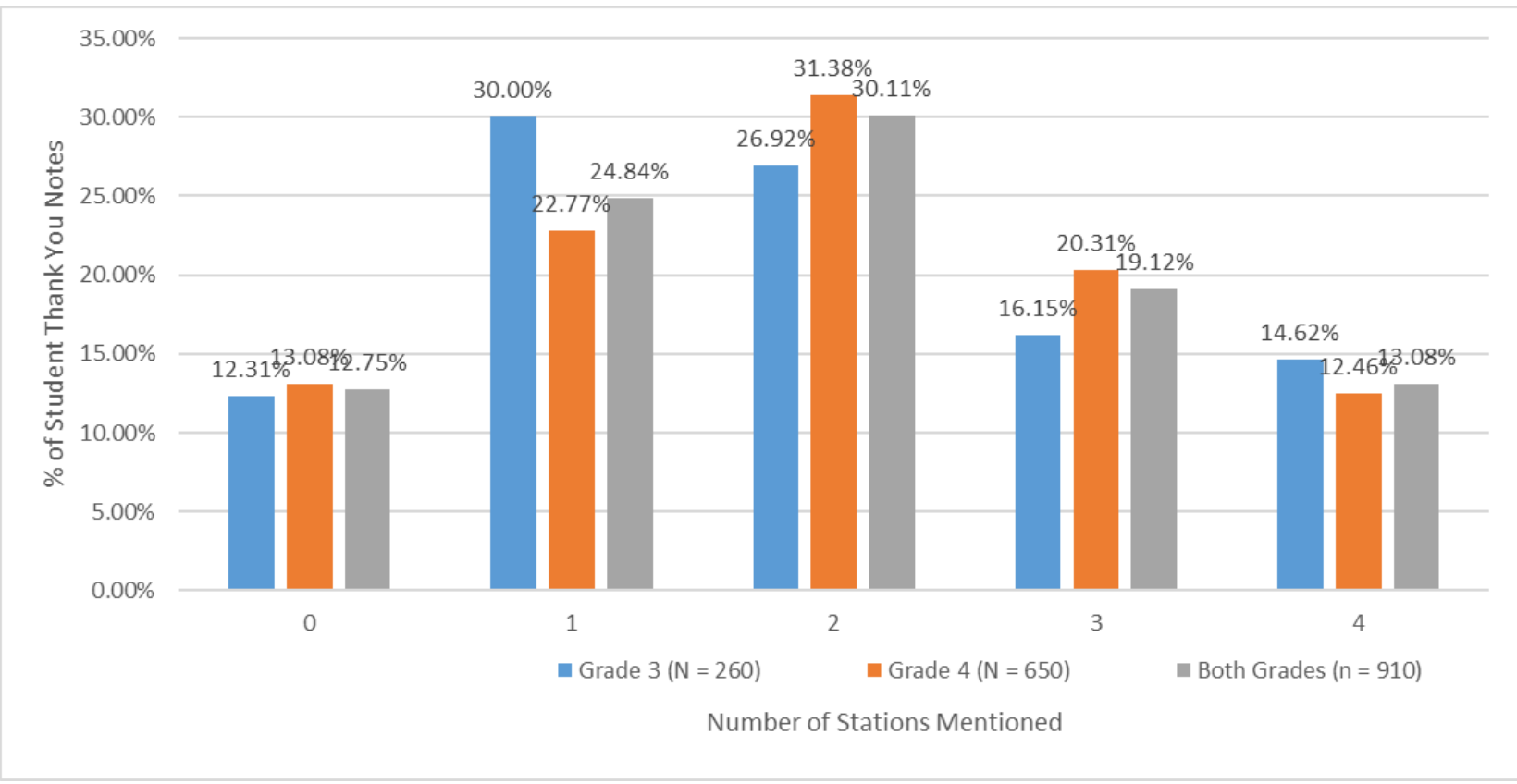

The post survey administered to the teachers showed that $97.8 \%$ of teachers stated that the field trip supports their classroom instruction. Teachers rated each station based on their perception of their students' overall experience. Combined means were calculated to show the results from these two grades. Each learning station was rated between 4.72 and 4.83 on a 5point scale, where 1 indicates poor and 5 indicates excellent. Figure 5 summarizes the combined mean teacher rating of student experiences at the field trip stations. 
Figure 5. Mean Teacher Rating of Student Experience at the Kids Growing with Grains Field Trip Stations (Third and Fourth Grades Combined)

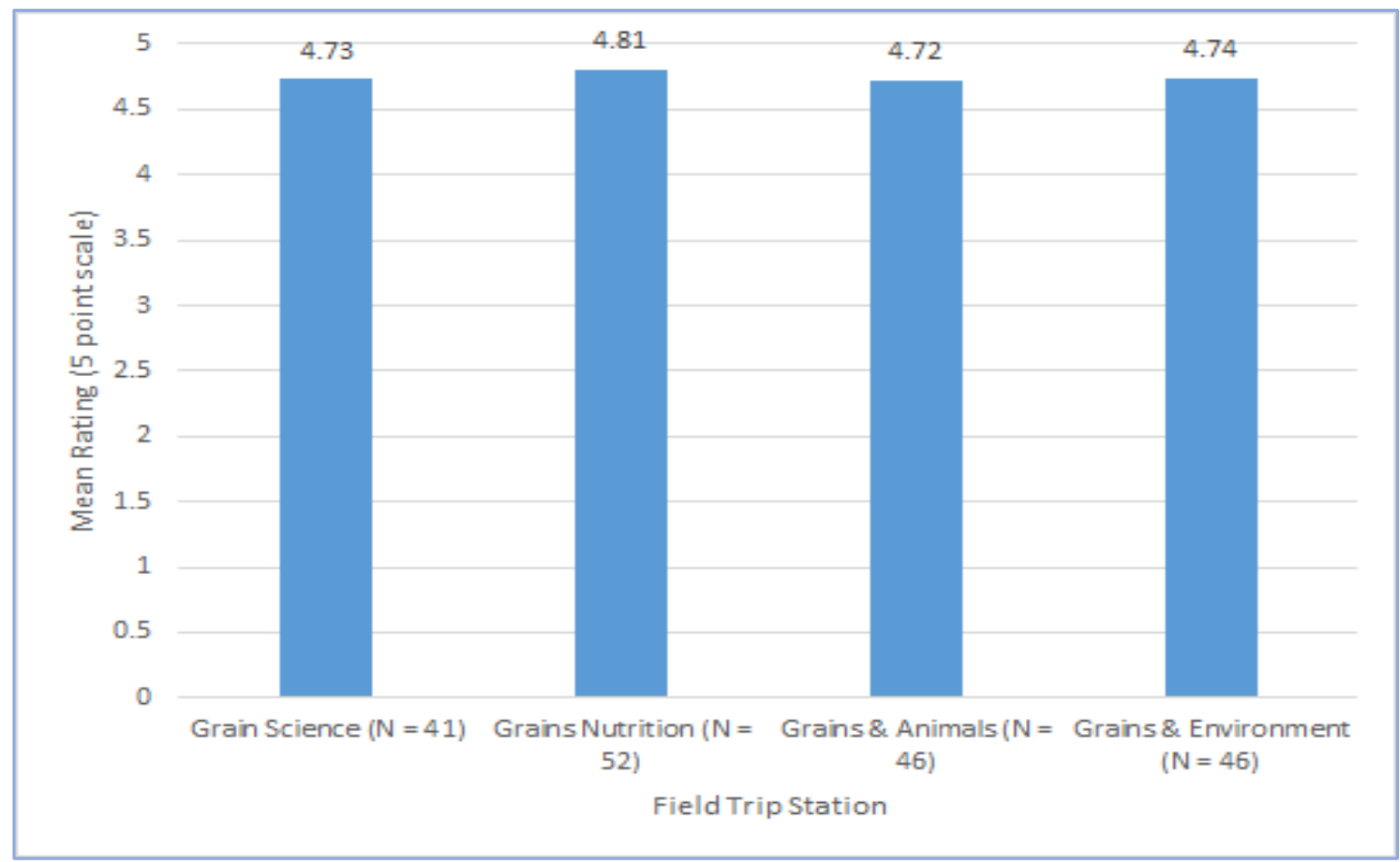

The Kruskal-Wallis test did not reach statistical significance, which indicates that there was no significant difference in how teachers rated the students' overall experience across four grain field trip stations $\left(\mathrm{X}^{2}(3, N=179)=.839, p=.840\right)$. Thus, teachers thought that all the field trip stations provided students with valuable experiences.

Based on the answers to the teacher qualitative survey questions, formal educators found immense value in the program. When asked to provide feedback or recommended changes for the learning stations, responses from both third- and fourth-grade teachers included the following themes:

- High value of overall experience: "All station leaders were great! Very knowledgeable and patient." and "Your program is amazing. Thank you for supporting our students and curriculum."

- Hands-on and engaging activities: "I think it's an engaging and excellent variety." and "I wouldn't change anything, this has so many hands-on experiences."

- Benefit of Spanish translations for students: "We really liked the parts of the packet that were in Spanish." and "I love the Spanish integration of resources for lessons." 
- Recommendations for the future: "If possible. More hands-on interactions with the animals." and "Describe what we are seeing on the straw ride."

In addition, when asked if there were any other changes they would recommend to the field trip, or for anything else they would like to share, responses from third- and fourth-grade teachers included the following themes:

- Curriculum connection from the field trip experience: "A very worthwhile learning experience was had by all because it was presented and planned by professionals with a definite curriculum connection." and "Thank you for this experience. There were many direct links to our curriculum like internal and external structures of plants and animals."

- Value of this experience for students: "Overall - I love this field trip. Many of our students never get an opportunity to see items like we do when we are here." and "Very motivating for students."

\section{Discussion and Limitations}

This article describes the Kids Growing with Grains program and the impacts it has on youth, measured through qualitative and quantitative data collection methods across both youth and teacher audiences.

One limitation to the evaluation is that the student survey relies on self-reporting to determine student understanding of a topic or concept. To overcome this potential limitation, we utilized several evaluation instruments that collected both quantitative and qualitative data from across teachers and students, allowing for triangulation across results. These results show that over $86 \%$ of students self-reported understanding the program's education topics, $62.31 \%$ of students recalled two or more of the stations in their thank-you notes, and $24.81 \%$ recalled one station. In addition, teachers report that the stations are providing a high-quality learning experience in their evaluations. Finally, student and teacher quotes suggest that the program provides a high-quality, experiential learning experience that achieves its learning objectives.

Youth mentioned the Grain Nutrition station the most (53.7\%) in their thank you notes; this was also the concept that the highest percentage of students reported understanding, with $94.61 \%$ understanding that grains are important ingredients in foods that we eat daily. However, only $72.28 \%$ reported that they will talk to their families about eating whole grains. This could be for a multitude of reasons and could be the focus of future studies. 
In addition, while $50.3 \%$ of students recalled the Grains and Animals station in their thank you notes, only $88.38 \%$ understood the topic in the post-field trip survey. This indicates that having a hands-on animal experience for youth results in remembering and enjoying the station, however the primary learning objective (of animals eating grains to produce things we eat and use) was not as clear to the youth.

It is also interesting to consider how many stations fourth and third graders mentioned, along with what percentage of students mentioned each station across grade levels. For fourth grade, $64.15 \%$ remember two or more stations in their thank-you notes and there is a fairly even distribution of students remembering each station, with $58 \%$ of students recalling the Grains and Environment station and between $42 \%$ and $48 \%$ mentioning the remaining three stations. However, only $57.69 \%$ of third graders mentioned two or more stations in their thank-you notes and there was a much larger difference in the percentage of students remembering each station. Approximately $30 \%$ of third-grade students mentioned the Grains and Environment and the Grain Science stations while between $63 \%$ and $68 \%$ mentioned the Grains and Animals station and the Grain Nutrition station. Why third graders mentioned fewer stations and mentioned the same stations more often could be due to overall station enjoyment or due to the scaffolding of instruction received by fourth graders enabling them to remember and mention more of the stations (resulting in a more even distribution of the stations mentioned).

The overall positive results across students' surveys, thank-you notes, and teacher surveys indicate that the program is achieving its educational objectives and growing student conceptual understanding of agriculture, nutrition, and the environment through experiential education. Students can apply this foundational knowledge to new situations and thereby continue their learning.

While the program impacts youth understanding of agriculture, nutrition, and the environment, it also likely has overall societal benefits in the long-term by educating youth regarding the importance of whole grains. Whole grain intake reduces mortality; Zong and colleagues (2016) found: "Our meta-analysis demonstrated inverse associations of WG [whole grain] intake with total and cause-specific mortality, and findings were particularly strong and robust for CVD [cardiovascular disease] mortality. These findings further support current Dietary Guidelines for Americans, which recommends at least 3 servings per day of WG intake" (p. 2370). 


\section{Kids Growing With Grains}

In addition to the difference this program can make on the health of youth, it also makes youth more aware of where their food comes from, thus allowing them to gain a better understanding of how agriculture affects their daily lives.

Lessons learned through the development and implementation of the Kids Growing with Grains program show value in getting to know the specific audience when teaching nutrition literacy; this ensures the content is relevant and inclusive. The Kids Growing with Grains program was designed to be highly adaptable in order to meet the needs of a wide range of audiences, including youth who live in urban, suburban, and rural settings and representing a range of demographic and socio-economic backgrounds. The program has strived to be responsive to the needs of diverse audiences, for example, providing translation for Spanish-speaking audiences. Engaging parents and families in nutrition education programs is also helpful, which our program does through our family engagement and take-home recipes.

Finally, nutrition literacy programs must aim to empower youth regarding their nutrition choices, by focusing on what youth can control in their daily food choices. It is extremely important to ensure youth do not feel guilty, or bad, about their choices. For instance, in the Kids Growing with Grains program, the activities talk about "sometimes" foods versus "always" foods, so that youth do not feel that a food they eat is labeled as a bad or unhealthy food.

Therefore, the Kids Growing with Grains program can serve as a valuable resource for any youth development professional looking for experiential learning opportunities that teach agricultural literacy, nutrition literacy, and healthy eating. The individual lessons can provide stand-alone activities, or a series of activities. These lessons can be utilized in a range of settings, such as classrooms, after-school programs, and camps. In addition, the program reinforces classroom instruction and aligns to national standards. It also presents an excellent opportunity for both in-school and after-school enrichment by youth development professionals.

\section{Future Considerations}

The program is currently expanding to include additional schools within the existing counties, including one new Title I school in Frederick County and several new Title I and private schools in Washington County. The program's complete curriculum will also be made available to interested educators for implementation across the United States in both school and out-ofschool settings. 
Future research should build upon the existing evaluation success by pairing questions asked of both third- and fourth-grade youth to assess changes in conceptual understanding across grade levels. In addition, student focus groups could be used to determine why fourth-grade students remember more concepts in their thank-you notes than third-grade students and had a more even distribution of the stations they mentioned.

While existing evaluations show improved student conceptual understanding of the topics, it is important in the future to determine how this conceptual understanding may shape student behavior, specifically whether or not students speak with their families about their experience, what they share, and why they did or did not share this information. This research should also assess the extent to which the knowledge gained by students influenced their and their families' future behaviors.

\section{References}

Balschweid, M. A., Thompson, G. W., \& Cole, R. L. (1998). The effect of agricultural literacy treatment on participating K-12 teachers and their curricula. Journal of Agricultural Education, 39(4), 1-10. https://doi.org/10.5032/jae.1998.04001

Barczewski, A., Bennett, S., Gordon, D., Hutson, T., \& BhaduriHauck, S. (2016). Using the AGsploration: the science of Maryland agriculture curriculum as a tool to increase youth appreciation and understanding of agriculture and science. Journal of Youth Development,11(3), 141-146. https://doi.org/10.5195/jyd.2016.467

Luckey, A. N., Murphrey, T. P., Cummins, R. L., \& Edwards, M. B. (2013). Assessing youth perceptions and knowledge of agriculture: The impact of participating in an AgVenture program. Journal of Extension, 51(3). https://www.joe.org/joe/2013june/rb3.php

Maryland State Archives (MSA). (2019). Maryland at a glance: Agriculture. https://msa.maryland.gov/msa/mdmanual/01glance/html/agri.html

McBeth, W., \& Volk, T. L. (2010). The National Environmental Literacy Project: A Baseline Study of Middle Grade Students in the United States. Journal of Environmental Education, 41(1), 55-67. https://doi.org/10.1080/00958960903210031

Pennisi, L. \& Lackey, N. Q. (2018). A multiyear evaluation of the NaturePalooza science festival. Journal of Extension, 56(7). https://www.joe.org/joe/2018december/rb4.php

Platt, J. C., Rusk, C. P., Blomeke, C. R., Talbert, B. A., \& Latout, M. A. (2008). A comparison of evaluation of digital versatile disc (DVD) instruction and live instruction in third grade classrooms. NACTA Journal, 52(1), 2-5. 
Journal of Youth Development | http://jyd.pitt.edu/ | Vol. 15 Issue 6 DOI 10.5195/jyd.2020.964

Kids Growing With Grains

State of Childhood Obesity. (n.d.). The state of obesity in Maryland. https://stateofchildhoodobesity.org/states/md/

Vierregger, A., Hall, J., Sehi, N., Abbott, M., Wobig, K., Albrecht, J. A., Anderson-Knott, M., \& Koszewski, W. (2015). Growing Healthy Kids: A school enrichment nutrition education program to promote healthy behaviors for children. Journal of Extension, 53(5).

https://joe.org/joe/2015october/iw3.php

Zong, G., Gao A, Hu, F. B., \& Sun, Q. (2016). Whole grain intake and mortality from all causes, cardiovascular disease, and cancer: A meta-analysis of prospective cohort studies. Circulation, 133(24), 2370-2380. https://doi.org/10.1161/circulationaha.115.021101 


\section{Appendix}

\section{Kids Growing with Grain Station Learning Objectives and Experiential Learning Elements}

Station: Grain science

\section{Learning objectives}

Grade 3: Students describe the different parts of a grain, using corn kernels as an example. Students explore how plants grow and the role of seeds in the plant life cycle. Students identify various uses of corn.

Grade 4: Students identify food products containing corn, the various uses of corn, and the role of corn in renewable resources, biodegradable products, and biofuels.

\section{Experiential learning elements}

Grade 3: Students play an interactive game identifying products that do and do not contain corn. They dissect corn kernels and edamame beans and sketch their findings. Finally, they eat a seed salad.

Grade 4: Students conduct an experiment with Styrofoam and corn-based packing peanuts to see which will dissolve in water. They then make corn putty or "Oobleck."

\section{Station: Grain nutrition}

\section{Learning objectives}

Grade 3: Students explore what makes a whole grain and the health benefits of eating whole grains. Students evaluate food labels to assess the nutritional content of their food.

Grade 4: Students compare and contrast different types of whole grain products, as well as the differences between whole and refined grains.

\section{Experiential learning elements}

Grade 3: Students act out how grains are planted and then made into flour for cooking. They then make and eat a whole grain pizza

Grade 4: Students taste test and review a variety of foods made from whole grains. Students grind raw grains into flour. In a second station completed at some of the field trips, students also make bread in a bag that is taken home to make with their families (note, this is not completed at all field trips, due to the length of time it takes some schools to travel and food safety issues). 


\section{Station: Grains and animals}

\section{Learning objectives}

Grade 3: Students identify the variety of products and uses people have for chickens and their eggs. Students explore the parts of an egg. Students discuss animal food, nutrition, and proper caretaking.

Grade 4: Students observe farm animals and describe their connection to agriculture and people. Students discuss proper feeding and nutrition for dairy cows.

\section{Experiential learning elements}

Grade 3: Students play a game identifying products containing chicken or egg products. They then study egg anatomy and then interact with a live hen or chicks.

Grade 4: Students touch and smell the different components of dairy cow food that make up their total mixed ration. They conduct an experiment that mirrors the cow's digestion of grains. They then interact with a live dairy cow or calf.

\section{Station: Grains and environment}

\section{Learning objectives}

Grade 3: Students explain the composition of soil. Students explore how water quality is impacted by different types of ground surface coverings.

Grade 4: Students analyze how grain plants grow in fields. Students identify various types of grains.

\section{Experiential learning elements}

Grade 3: Students touch and identify sand, silt, and clay. They then conduct a "soil shake up" experiment, mixing soil with water in a jar. They make hypotheses regarding how the soil and water will interact and then observe and draw conclusions after the field day in their classrooms.

Grade 4: Students touch various types of grains and prepare grain jars filled with a variety of different grains to take home and share with their families. Students go on a hayride tour of the farm. 